TECHNICAL TRANSACTIONS 11/2017

CZASOPISMO TECHNICZNE 11/2017

ENVIRONMENTAL ENGINERING

DOI: $10.4467 / 2353737 X C T .17 .197 .7426$

\author{
Małgorzata Kryłów (gosiak@wis.pk.edu.pl) \\ Piotr Rezka \\ Institute of Water Supply and Environmental Protection, Faculty of Environmental \\ Engineering, Cracow University of Technology
}

\title{
SOURCES OF ENDOCRINE-DISRUPTING COMPOUNDS AND THEIR MIGRATION TO THE ENVIRONMENT
}

\author{
ŹRÓDŁA ZWIĄZKÓW ZABURZAJĄCYCH FUNKCJONOWANIE UKŁADU \\ HORMONALNEGO I ICH MIGRACJA W ŚRODOWISKU
}

\begin{abstract}
The aim of this article is to present issues related to the presence and pathways of bisphenol A emission and its migration to wastewater and the environment. Bisphenol A (BPA) is an organic compound mainly used in the production of plastics. It is classified as an endocrine disrupting compound (EDC) and should therefore not be emitted to the environment. This paper presents basic information on bisphenol A, its applications and potential sources of emission to the environment. A wide review of literature confirming the occurrence of bisphenol A in sewage, sediments, natural waters, drinking water and the atmosphere is performed. Effective wastewater treatment and neutralisation of bisphenol A in sewage sludge could partially reduce the levels of BPA pollution in the aquatic environment.
\end{abstract}

Keywords: bisphenol A (BPA), wastewater, water, sediments, air

\section{Streszczenie}

Celem artykułu jest przedstawienie zagadnień dotyczących obecności i źródeł występowania bisfenolu A w ściekach i środowisku. Bisfenol A (BPA) jest związkiem organicznym, stosowanym przede wszystkim do produkcji tworzyw sztucznych. Należy do związków wykazujących negatywne oddziaływanie na układ hormonalny (endocrine disrupting compounds, EDC), w związku z czym nie powinien być emitowany do środowiska naturalnego. W artykule przedstawiono podstawowe informacje dotyczące bisfenolu A oraz potencjalne źródla emisji tego związu do środowiska. Dokonano przeglądu literatury potwierdzającej obecność bisfenolu A w ściekach, osadach oraz wodach naturalnych. Efektywne oczyszczenie ścieków i neutralizacja bisfenolu A obecnego w osadach ściekowych pozwoliłoby na częściowe ograniczenie zanieczyszczenia środowiska naturalnego.

Słowa kluczowe: bisfenol A (BPA), ścieki, woda, osady, powietrze 


\section{Introduction}

The presence of organic contaminants in the environment has been studied for many years. Pesticides, solvents, substances used in industry and, relatively recently, pharmaceuticals have also become one of the most discussed topics in this context in scientific publications worldwide. Another group of environmental pollutants are endocrine-disrupting compounds or chemicals (EDCs) which affect the endocrine (hormonal) systems of living organisms. These compounds are characterised by an extremely negative impact on the environment and human health at very low concentrations.

Natural and synthetic oestrogens have adverse effects on aquatic organisms at concentrations as small as $0.1 \mathrm{ng} / 1$ [24], they are toxic to humans and pose a risk through the consumption of fish and other animals living in water and exposed to these hormones. The other substance from the EDC group, bisphenol A, is a compound used on a very large scale and people are exposed to its harmful effects at work, in stores, on walks or even at home. Indirectly, logistics processes, such as transportation, waste disposal and management of waste are sources of environmental pollution from this compound.

The purpose of this paper is to present bisphenol $\mathrm{A}$ as a commonly occurring and harmful pollutant, its sources of emissions to the environment and the results of global research showing the presence of bisphenol A in wastewater, natural water, sediment and air samples.

\section{Characteristic}

Bisphenol A (BPA) is an organic chemical compound belonging to the phenol group. Its solid state is most commonly a white powder or flakes. It has a low level of solubility in water, but is soluble in metal hydroxides from alkali metal and organic solvents such as acetone, methanol, ethanol and diethyl ether. Table 1 presents basic information on BPA, such as molar mass, molecular formula and structure, and half-life in the human organism.

Table 1. Basic parameters of bisphenol A

\begin{tabular}{|l|c|c|c|c|}
\hline Compound & Formula & Structure & $\begin{array}{c}\text { Molecular } \\
\text { mass } \\
{[\mathbf{g} / \mathbf{m o l}]}\end{array}$ & CAS no. \\
\hline $\begin{array}{c}\text { Bisphenol A } \\
\text { (BPA) }\end{array}$ & $\mathrm{C}_{15} \mathrm{H}_{16} \mathrm{O}_{2}$ & & 228.29 & $80-05-7$ \\
\hline
\end{tabular}

The first method of preparation of BPA was its synthesis by two molecules of acetone and phenol in acidic conditions. This method was efficient (under the excess of phenol), and had an important advantage in the fact that the only by-product was water; however, the commercial production of BPA requires the large-scale distillation of a mixture of many by-products. 
Bisphenol $\mathrm{A}$ is classified as an endocrine-disrupting substance which has a negative impact on the hormonal system of humans and animals mimicking the effect of female hormones (oestrogens); furthermore, the exposure of foetuses to BPA can trigger subsequent physical and neurological problems. It is also suspected of carcinogenicity and because of that, bisphenol A was classified as a compound which is extremely hazardous to humans and the environment.

\section{Potential sources of emission}

Figure 1 illustrates the potential sources ofEDC (includingBPA) release to the environment. Bisphenol A is widely used in the production of plastics, especially polycarbonate resins e.g. it is an essential monomer for epoxy resin. Such materials are used in the manufacture of a wide range of products, these include polycarbonate plastics, water bottles, baby bottles, sports equipment, CDs and DVDs, medical devices, dental sealants for teeth fillings, optical lenses and lining for water pipes. Epoxy resins containing BPA are used as linings for cans of food and beverages. Bisphenol $\mathrm{A}$ is also used as an antioxidant and an inhibitor in the production and processing of polyvinyl chloride, in the manufacture of car tyres, as flame retardant, in electronics, within the construction industry, in moulding and in the production of thermal paper for receipts [8]. This means that bisphenol A and materials produced with BPA are in widespread use in industrialised and developing countries.

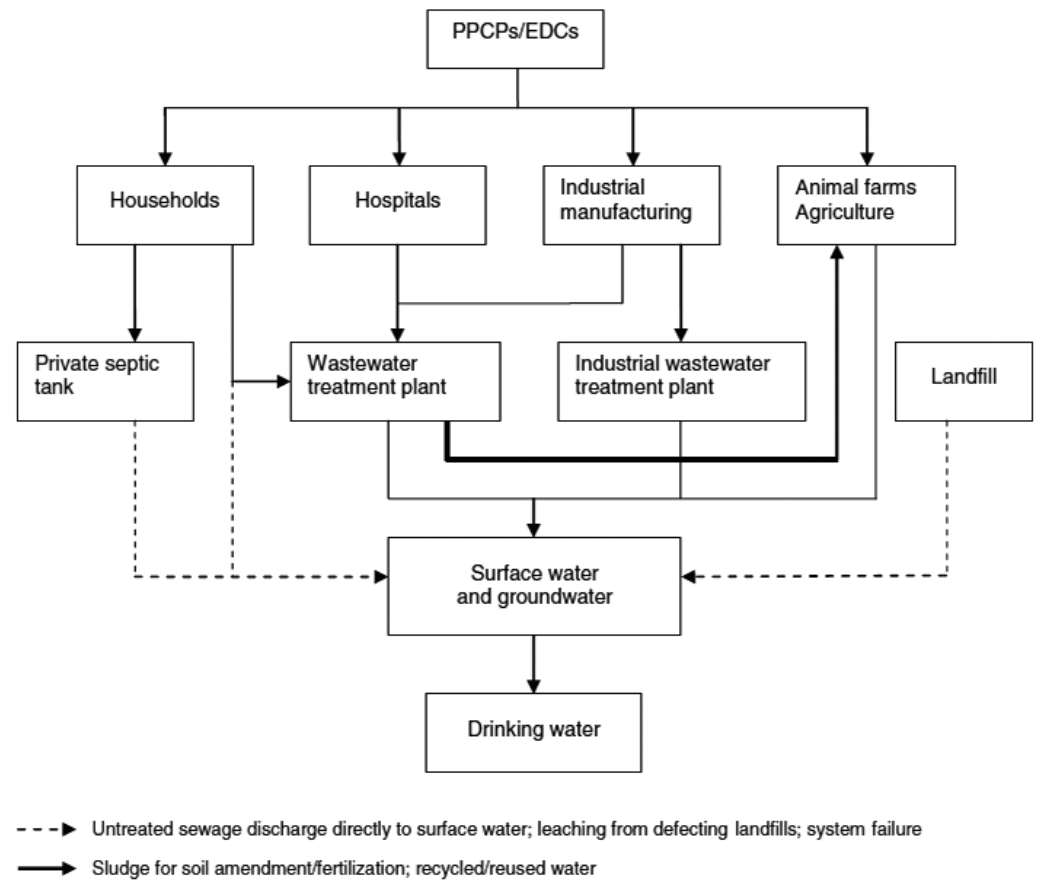

Fig. 1. Sources of endocrine-disrupting compounds (EDC) in the environment [7] 
The main modes of human exposure to BPA are its ingestion, inhalation and contact with skin. Most BPA is ingested along with food, drinking water and beverages in cans and bottles, and tap water (due to the linings of water pipes containing BPA). Penetration into the body through skin may occur during normal use of products containing BPA, especially in the case of thermal paper receipts in which BPA is present in its free state (not in the form of polymer product) - this constitutes an increased risk of exposure to BPA for cashiers and customers. The penetration of bisphenol A into the body via inhalation may occur particularly while inhaling urban air polluted with BPA, being near a cash register during the printing of receipts and potentially during the recording of CDs and DVDs because the laser heats the plate to sometimes even up to $700^{\circ} \mathrm{C}$. BPA is excreted primarily in urine, which is why household sewage is a significant source of BPA in raw wastewater within wastewater treatment plants [10].

The transportation, storage and disposal of waste containing BPA also poses a risk of environmental pollution. The presence of materials containing BPA in car tyres creates a continual risk of pollution through the abrasion of the tyres. Tyre particles may be blown into neighbouring roads and meadows and in the right conditions, it can also lead to BPA penetration into soil. Transportation or storage in landfills of inadequately protected materials that contain BPA also poses a risk of wastes spreading across the environment. Emissions to soil and groundwater can occur by eluting residues of BPA in precipitations from products containing it e.g. thermal paper. The combustion of materials containing bisphenol A also contributes to the pollution of the environment, in this case the atmosphere; however, the primary source of BPA in air samples is the production of BPA itself.

\section{Occurrence in the environment}

Bisphenol A present in the wastewater fed to the municipal wastewater stream comes mainly from wastewater produced in households and from industrial effluents that have been pre-screened and then discharged to the municipal treatment plant. Table 2 presents the confirmed cases of BPA detection in sewage treatment plants (raw and treated wastewater), natural waters and sewage sludge and sediments. Insufficient degradation or elimination of BPA during wastewater treatment processes results in the emission of BPA with the discharge of effluent into rivers or reservoirs and contamination of the aquatic environment.

The presence of BPA in the aqueous environment is not only related to effluent discharged from urban wastewater treatment, but also to pre-treated wastewater discharged directly from the factories and industrial wastewater treatment plants. If polluted wastewater is discharged into a body of water which is a tributary to other watercourses, bisphenol A will migrate and contaminate another river or even groundwater. The data reported in Table 2 confirms the ability of BPA to migrate into groundwater through, among other routes, permeable layers. BPA can also partially accumulate by passing through soil and river sediments. 
Table 2. Concentrations (min-max or mean) in ng/l or ng/g dry mass for sediments of BPA; b.l.q. - below level of quantification

\begin{tabular}{|c|c|c|c|c|}
\hline Influent & Effluent & Surface water & Groundwater & Sediments \\
\hline $\begin{array}{c}13-2140^{[15]} \\
60-600^{[43]} \\
360-1620^{[18]} \\
378-890^{[9]} \\
416-2050^{[23]} \\
1800^{[40]}\end{array}$ & $\begin{array}{c}2-44^{[43]} \\
30-1100^{[15]} \\
35-86^{[23]} \\
110-300^{[18]} \\
700^{[40]}\end{array}$ & $\begin{array}{c}1.2-1900^{[1]} \\
2.1-87^{[13]} \\
2.2-4230^{[21]} \\
6-34^{[23]} \\
6-68^{[11]} \\
6-500^{[26]} \\
6-881^{[22]} \\
7.5-334^{[12]} \\
55-162^{[27]} \\
192-215^{[15]} \\
460-4800^{[25]}\end{array}$ & $\begin{array}{c}\text { b.l.q.- } 494^{[17]} \\
\text { b.l.q.-7000 } \\
\text { b.l.q. }-9300^{[28]} \\
1-1136^{[20]} \\
1-11^{[4]} \\
79-2550^{[15]} \\
600-11000^{[14]}\end{array}$ & $\begin{array}{c}0.17-1.25^{[2]} \\
0.58-36700^{[8]} \\
1.1-43^{[42]} \\
4.3-130^{[25]} \\
10-530^{[23]} \\
53-196^{[43]} \\
0.32^{[6]}\end{array}$ \\
\hline
\end{tabular}

$\mathrm{Fu}$ and Kawamura [5] showed that bisphenol $\mathrm{A}$ is also present in air samples. In the agricultural areas of China, its concentration in the air does not exceed $240 \mathrm{pg} / \mathrm{m} 3$, but the air samples in urban areas are more contaminated $\left(20-2.340 \mathrm{pg} / \mathrm{m}^{3}\right)$. Definitely, more air pollution bisphenol was found in India, where its concentration reached 9,820 and $17,400 \mathrm{pg} / \mathrm{m}^{3}$. Air samples collected in coastal areas around the world contain trace amounts of BPA that does not exceed $32 \mathrm{pg} / \mathrm{m}^{3}$. These results show how large the scale of bisphenol A pollution is in the environment - it is not only water that is contaminated but also the air and soil. Considering how large is the current need for BPA (despite attempts to withdraw from the production and use of bisphenol A in Canada), constantly increasing levels of environmental pollution can be expected.

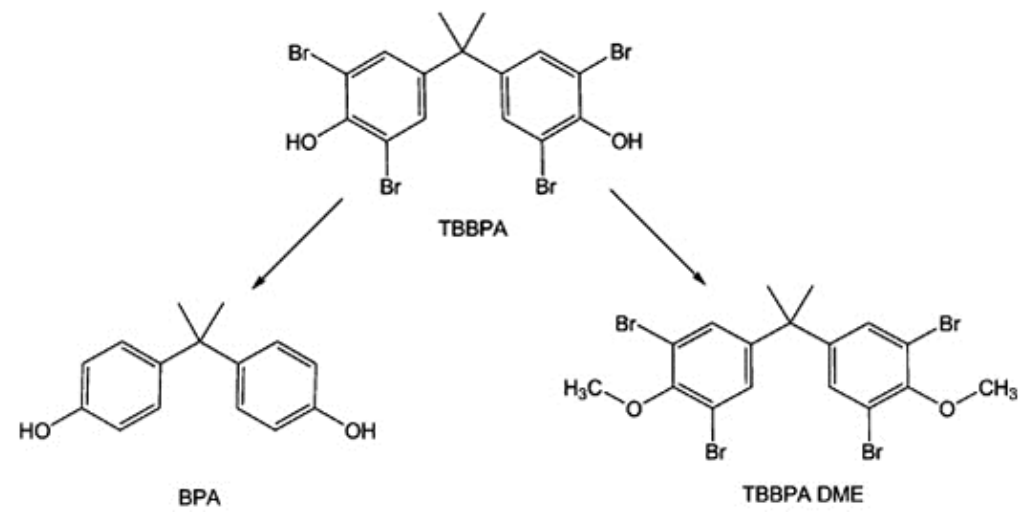

Fig. 2. Microbial-induced transformation of TBBPA to BPA and TBBPA DME [16]

It should be kept in mind that the presence of BPA in the environment can be linked not only with BPA itself, but also with more complex compounds that may transform into BPA. One of the most widely used brominated flame retardants, tetrabromobisphenol A (TBBPA) - depending on the conditions under the influence of bacteria present in the environment, this can be transformed into BPA (reductive debromination in anaerobic conditions), 
TBBPA DME (dimethyl ether) and TBBPA monomethyl ether (O-methylation in aerobic conditions) (Fig. 2). This may explain the very high concentrations of BPA in groundwater (anaerobic conditions).

\section{BPA in other matrixes}

Previously mentioned data provides a picture of the wide migration of bisphenol A occurring in the aquatic environment. Bisphenol emitted to sewage or directly to surface water may accumulate in sewage sludge or river sediments; the use of such sludge for agricultural purposes may contribute to even greater levels of BPA pollution of soils.

If bisphenol $\mathrm{A}$ is present in the source water of a drinking water treatment plant, there is a risk that it can penetrate to the finished water despite the use of modern methods of treatment. There are known cases of bisphenol A detection in drinking water in China between $15-63 \mathrm{ng} / \mathrm{l}$ and $38.9-55.8 \mathrm{ng} / \mathrm{l}$ [8]; in Canada, $100 \mathrm{ng} / \mathrm{l}$; in the USA, up to $24 \mathrm{ng} / \mathrm{l}$ [15]; also in other countries at concentrations not exceeding $100 \mathrm{ng} / \mathrm{l}(0.5-99 \mathrm{ng} / \mathrm{l})[1]$.

Ingestion of drinking water polluted with bisphenol $A$ is an additional route of exposure of the human body to BPA. Studies have shown that BPA was detected in the analysed samples of blood serum and urine at concentrations of 0-2,500 ng/l in serum and 110-3,200 ng/l in urine [41]. Also in Japan, BPA was detected in 23 samples of breast milk at concentrations of 280-970 ng/1 [29]. This confirms the suspicion of the possibility of exposure of infants and young children to the harmful effects of BPA.

\section{Conclusions}

Bisphenol A is ubiquitous in the environment, not only in effluents and natural waters, but also in soil and the atmosphere. Its wide use hinders any control over the level and scale of pollution and calls into question any plans to withdraw the substance from production. Due to its advantages, in many countries bisphenol $\mathrm{A}$ is and will be the main raw material for the production of polycarbonate plastic used in the production of baby bottles. The first step should be the removal of BPA from everyday life where it is not needed and poses a direct threat to the body, especially for infants and young children (replacing linings in pipes and removing the material from the production of baby bottles). The next step should be to protect the air in workplaces (BPA withdrawal from the production of thermal paper) and areas adjacent to factories producing or using bisphenol A.

This does not mean that we need not care about the environment itself. Inefficient wastewater treatment and inadequate protection of landfill result in pollution of water and soil - this could ultimately mean exposure to human health through repeated contact with BPA. The application of membrane processes using reverse osmosis (RO) and nanofiltration (NF) could be used for efficient BPA removal. Experiments conducted by Dudziak and Bodzek [3] showed $85 \%$ and $70 \%$ reductions of bisphenol A from water solutions through 
the use of RO and NF, respectively. Contaminated agricultural land (and consequently crop yields) and drinking water containing bisphenol $\mathrm{A}$ are additional sources of penetration of the harmful compound to the human body.

\section{References}

[1] Benner J., Helbling D.E., Kohler H.-P.E., Wittebol J., Kaiser E., Prassem C., Ternes T.A., Albers C.N., Aamand J., Horemans B., Springael D., Walravens E., Boon N., Is biological treatment a viable alternative for micropollutant removal in drinking water treatment processes?, Water Research, Vol. 47, 2013, 5955-5976.

[2] Dong B., Kahl A., Cheng L., Vo H., Ruehl S., Zhang T., Snyder S., Saez A.E., Quanrud D., Arnold R.G., Fate of trace organics in a wastewater effluent dependent stream, Science of the Total Environment, Vol. 518-519, 2015, 479-490.

[3] Dudziak M., Bodzek M., Removal of Estrogenic Micropollutants from Water Solutions by High-Pressure Driven Membrane Processes, Ochrona Środowiska, Vol. 31 (2), 2009, 33-36.

[4] Felix-Canedo T.E., Duran-Alvarez J.C., Jimenez-Cisneros B., The occurrence and distribution of a group of organic micropollutants in Mexico City's water sources, Science of the Total Environment, Vol. 454-455, 2013, 109-118.

[5] Fu P.Q. Kawamura K., Ubiquity of bisphenol $A$ in the atmosphere, Environmental Pollution, Vol. 158, 2010, 3138-3143.

[6] Gardner M., Jones V., Comber S., Scrimshaw M.D., Coello-Garcia T., Cartmell E., Lester J., Ellor B., Performance of UK wastewater treatment works with respect to trace contaminants, Science of the Total Environment, Vol. 456-457, 2013, 359-369.

[7] Grassi M., Rizzo L., Farina A., Endocrine disruptors compounds, pharmaceuticals and personal care products in urban wastewater: implications for agricultural reuse and their removal by adsorption process, Environmental Science and Pollution Research, Vol. 20, 2013, 3616-3628.

[8] Huang Y.Q. Wong C.K.C., Zheng J.S., Bouwman H., Barra R., Wahlstrom B., Neretin L., Wong M.H., Bisphenol A (BPA) in China: A review of sources, environmental levels, and potential human health impacts, Environment International, Vol. 42, 2012, 91-99.

[9] Jiang J.Q. Yin Q. Zhou J.L., Pearce P., Occurrence and treatment trials of endocrine disrupting chemicals (EDCs) in wastewaters, Chemosphere, Vol. 61, 2005, 544-550.

[10] Kang J.-H., Kondo F., Katayama Y., Human exposure to bisphenol A, Toxicology, Vol. 226, 2006, 79-89.

[11] Kasprzyk-Hodern B., Dinsdale R.M., Guwy A.J., The removal of pharmaceuticals, personal care products, endocrine disruptors and illicit drugs during wastewater treatment and its impact on the quality of receiving waters, Water Research, Vol. 43, 2009, 363-380.

[12] Kim J.W., Jang H.S., Kim J.G., Ishibashi H., Hirano M., Nasu K., Ichikawa N., Takao Y., Shinohara R., Arizono K., Occurrence of Pharmaceutical and Personal Care Products (PPCPs) in Surface Water from Mankyung River, South Korea, Journal of Health Science, Vol. 55, 2009, 249-258. 
[13] Kleywegt S., Pileggi V., Yang P., Hao C., Zhao X., Rocks C., Tchach S., Cheung P., Whitehead B., Pharmaceuticals, hormones and bisphenol $A$ in untreated source and finished drinking water in Ontario, Canada - occurrence and treatment efficiency, Science of the Total Environment, Vol. 409, 2011, 1481-1488.

[14] Lapworth D.J., Baran N., Stuart M.E., Ward R.S., Emerging organic contaminants in groundwater: a review of sources, fate and occurrence, Environmental Pollution, Vol. 163, 2012, 287-303.

[15] Luo Y., Guo W., Ngo H.H., Nghiem L.D., Hai F.I., Zhang J., Liang S., Wang X.C., $A$ review on the occurrence of micropollutants in the aquatic environment and their fate and removal during wastewater treatment, Science of the Total Environment, Vol. 473474, 2014, 619-641.

[16] McCormick J.M., Paiva M.S., Haggblom M.M., Cooper K.R., White L.A., Embryonic exposure to tetrabromobisphenol $A$ and its metabolites, bisphenol $A$ and tetrabromobisphenol A dimethyl ether disrupts normal zebrafish (Danio rerio) development and matrix metalloproteinase expression, Aquatic Toxicology, Vol. 100 (3), 2010, 255-262.

[17] Meffe R., de Bustamante I., Emerging organic contaminants in surface water and groundwater: A first overview of the situation in Italy, Science of the Total Environment, Vol. 481, 2014, 280-295.

[18] Moral A., Sicilia M.D., Rubio S., Perez-Bendito D., Determination of bisphenols in sewage based on supramocelular solid-phase extraction/liquid chromatograpy/fluorimetry, Journal of Chromatography A, Nr 1100, 2005, 8-14.

[19] Musolff A., Leschik S., Moder M., Strauch G., Reinstorf F., Schirmer M., Temporal and spatial patterns of micropollutants in urban receiving waters, Environmental Pollution, Vol. 157, 2009, 3069-3077.

[20] Osenbruck K., Glaser H.-R., Knoller K., Weise S.M., Moder M., Wennrich R., Sources and transport of selected organic micropollutants in urban groundwater underlying the city of Halle (Saale), Germany, Water Research, Vol. 41, 2007, 3259-3270.

[21] Pal A., He Y., Jekel M., Reinhard M., Gin K.Y.H., Emerging contaminants of public health significance as water quality indicator compounds in the urban water cycle, Environment International, Vol. 71, 2014, 46-62.

[22] Peng X., Yu Y., Tang C., Huand Q. Wang Z., Occurrence of steroid estrogens, endocrinedisrupting phenols and acid pharmaceutical residues in urban riverine water of the Pearl River Delta, South China, Science of the Total Environment, Vol. 937, 2008, 158-166.

[23] Petrie B., Barden R., Kasprzyk-Hodern B., A review onemerging contaminantsin wastewaters and the environment: Current knowledge, understudied areas and recommendations for future monitoring, Water Research, Vol. 72, 2015, 3-27.

[24] Rezka P., Balcerzak W., Kryłów M., Occurrence of synthetic and natural estrogenic hormones in the aquatic environment, Technical Transactions, Vol. 3-Ś/2015, 47-54.

[25] Salgueiro-Gonzalez N., Turnes-Carou I., Besada V., Muniategui-Lorenzo S., Lopez-Mahia P., Prada-Rodriguez D., Occurrence, distribution and bioaccumulation of endocrine disrupting compounds in water, sediment and biota samples from a European river basin, Science of the Total Environment, Vol. 529, 2015, 121-130. 
[26] Santhi V.A., Sakai N., Ahmad E.D., Mustafa A.M., Occurrence of bisphenol A in surface water, drinking water and plasma from Malaysia with exposure assessment from consumption of drinking water, Science of the Total Environment, Vol. 427-428, 2012, 332-338.

[27] Stasinakis A.S., Mermigka S., Samaras V.G., Farmaki E., Thomaidis N.S., Occurrence of endocrine disrupters and selected pharmaceuticals in Aisonas River (Greece) and environmental risk assessment using hazard indexes, Environmental Science and Pollution Research, Vol. 19, 2012, 1574-1583.

[28] Stuart M., Lapworth D., Crane E., Hart A., Review of risk from potential emerging contaminants in UK groundwater, Science of the Total Environment, Vol. 416, 2012, $1-21$.

[29] Sun Y., Irie M., Kishikawa N., Wada M., Kuroda N., Nakashima K., Determination of bisphenol $A$ in human breast milk by HPLC with column-switching and fluorescence detection, Biomedical Chromatography, Vol. 18, 2004, 501-507.

[30] Tadkaew N., Hai F.I., McDonald J.A., Khan S.J., Nghiem L.D., Removal of trace organics by MBR treatment: The role of molecular properties, Water Research, Vol. 45, 2011, 2439-2451.

[31] Vanderberg L.N., Hausen R., Marcus M., Olea N., Welshons W.V., Human exposure to bisphenol A (BPA), Reproductive Toxicology, Vol. 24, 2007, 139-177.

[32] Vethaak A.D., Lahr J., Schrap S.M., Belfroid A.C., Rijs G.B.J., Gerritsen A., de Boer J., Bulder A.S., Grinwis G.C.M., Kuiper R.V., Legler J., Murk T.A.J., Peijnenburg W., Verhaar H.J.M., de Voogt P., An integrated assessment of estrogenic contamination and biological effects in the aquatic environment of The Netherlands, Chemosphere, Vol. 59, 2005, 511-524.

[33] Yu Y., Wu L., Chang A.C., Seasonal variation of endocrine disrupting compounds, pharmaceuticals and personal care products in wastewater treatment plants, Science of the Total Environment, Vol. 442, 2013, 310-316. 